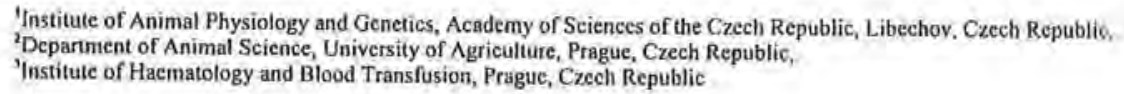
JOSEF MATOUSEK ${ }^{\prime}$, VOJTECH HRUBAN ${ }^{2}$,JAN HRADECKY ${ }^{1}$, ALENA HRUBA ${ }^{3}$
and JOSEF SOUCEK

\title{
Effect of bovine seminal ribonuclease (BS-RNase) on pig's bone marrow cells
}

\section{Summary}

The effect of bovine seminal ribonuclease (BS RNase) on bone marrow cells in miniature pigs was studied. BS RNase at the concentration 20 and $100 \mu \mathrm{g} / \mathrm{ml}$ preincubated $1 \mathrm{~h}$ with bone marrow cells from normal miniature pigs did not influence the formation of CFU-GM and BFU-E colonies cultivated in methylcellulose medium. The bone marrow cells kept in $4^{\circ} \mathrm{C}$ survived better in the presence of BS RNase than control cells cocultivated with bovine serum albumin (BSA). There was proved that pig bone marrow cells are able to bind the BS RNase on their surface without any morphological damage. For the experimental bone marrow transplantation in miniature pigs the whole body irradiation of $8 \mathrm{G}$ with a cobalt source was used. Two recipients from seven accepted semi-incompatible bone marrow cells preincubated $2 \mathrm{~h}$ with BS RNase $\left(10 \mathrm{mg} / 5 \times 10^{\mathrm{B}}\right.$ cells). No recipient from eight transplanted control animals accepted semi-incompatible bone marrow cells preincubated with BSA.
\end{abstract}

Key Words: miniature pigs, bovine seminal ribonuclease, bone marrow transplantation, antigens

\section{Zusammenfassung}

Titel der Arbeit: Der Effekt von bovimer seminaler Ribonuclease in Knochenmarkzellen beim Miniaturschwein

Untersucht wurde der Effekt der bovinen seminalen Ribonuklease (BS RNase) bei Miniaturschweinen. Die BS RNase, die in Konzentrationen von 20 und $100 \mu \mathrm{g} / \mathrm{ml}$ eine Stunde mit den Knochenmarkzellen der normalen Minischweine präinkubiert wurde, hatte keinen Einfluß auf das Wachstum der CFU-GM und BFU-E Kolonien, die im Methylzellulosemedium kultiviert worden sind. Die bei $4^{\circ} \mathrm{C}$ kultivierten Knochenmarkzellen überlebten mit BS RNase besser als mit bovinem Serumalbumin (BSA). Es ist nachgewiesen worden, dass die Schweineknochenmarkzellen fähig sind die BS RNase auf ihrer Oberfläche ohne morphologische Schadigung zu binden. Für die experimentelle Knochenmarktransplantation bei Miniaturschweinen wurde die Ganzkơrperbestrahlung (8G) mit der Kobaltbombe angewendet. Zwei von sieben Rezipienten nahmen semiinkompatibele Knochenmarkzellen, die zwei Stunden mit BS RNase $\left(10 \mathrm{mg} / 5 \times 10^{8}\right.$ Zellen) präinkubiert wurden, auf. Von acht transplantierten Kontrolltieren nahm kein Rezipient semiinkompatibele Knochenmarkzellen, die zwei Stunden mit BS RNase ( $10 \mathrm{mg} / 5 \times 10^{8}$ Zellen) präinkubiert wurden, auf. Ebenfalls nahm von acht transplantierten Kontrolltieren kein Rezipient semiinkompatibele Knochenmarkzellen, die mit BSA präinkubiert wurden, auf.

Schlasselwörter: Miniaturschwein, bovine seminale Ribonuklease, Knochenmarktransplantation, Antigene

\section{Introduction}

Spermatozoa are foreign cells for reproductive organs of females. They must be protected for a certain time against female immune cells and production of antibodies. This protection probably occures in both sexes: male and female. Numerous studies showed that human and animal seminal plasma and spermatozoa includes many immunosuppressive substances (SHIVAJI et al., 1990).

The bovine seminal ribonuclease (BS-RNase) is an antitumor and immunosuppressive 
substance which was determined in the bull seminal plasma (MATOUŠEK, 1985; D'ALESSIO et al., 1991) and using an ELISA method in a very large amount (in average $1132 \mu \mathrm{g} / \mathrm{ml}$ - MATOUŠEK and KLAUDY, 1998). The biological properties of BS-RNase were accounted to its dimeric form, since this structure is unique among the vertebrate RNase superfamily (D'ALESSIO et al,, 1991). The DNA sequence of the gene encoding BS-RNase was determined and recombinant preparation of BSRNase was synthetized (KIM and RAINES, 1993; DE NIGRIS et al., 1993). We have found that the biological activities, including the immunosuppressive effect, are identical with these of the native BS-RNase (KIM et al., 1995). The potent immunosuppressive activity of this enzyme and its favourable effect on hemopoietic cells in animal and human bone marrow cultures (STANĚK et al., 1978, 1982; SOUČEK et al., 1981, 1986, 1996; TAMBURINI et al., 1990) urged us to examine BS-RNase effect on experimental bone marrow transplantation in semi-incompatible miniature pigs.

\section{Animals}

Materials and methods

Miniature pigs (Minnesota type), 6-15 kg weight and 3-5 months old, were selected for the lymphocytes, bone marrow cells and transplantation experiments. All animals were bred at our Animal Centre. Pigs from single letters were typed for the blood groups and histocompatible antigens 14-20 days before transplantation. The selected pigs were penned at least 4 days prior to bone marrow transplantation and during posttransplantation time individually. The experimental house was sterilized by germicide lamps before the pig's housing. The animals were systematically deparasitized.

\section{Ribonucleases and other substances}

Bovine seminal ribonuclease (BS-RNase) was isolated from bull seminal plasma by precipitation with acetic acid and amonium sulphate and the supernatant subjected to CM Sephadex C-50 and Sephadex G-100 column chromatography (DOSTÁL and MATOUŠEK, 1973). Bovine pancreatic ribonuclease (RNase A) was obtained from ICN Biomedicals Inc., USA. Phytohemagglutinin (PHA) was obtained from Wellcome Diagnostics, England. Swine anti-rabbit IgG/FITC was produced by USOL, Prague, Czech Republic. Anti-BS-RNase antibodies were produced by reimmunization of two rabbits and IgG isolated. Verografin (produced by Léčiva, Prague) was used for isolation of lymphopcytes. The bovine serum albumin (BSA) was obtained from the Institute of Sera and Vaccines, Prague. RPMI 1640 and MEM medium were obtained from the Institute of Haematology and Blood Transfusion, Prague.

\section{Estimation of Colony-Forming Activity}

Bone marrow cells obtained by a puncture of vertebral bodies and ribs of fresh killed pigs were suspended in Iscove medium mixed $1: 1$ with $A C D$ and supplemented with $10 \%$ of FCS, antibiotics and heparin $(20 \mathrm{IU} / \mathrm{ml})$. Colony-forming activity of hematopoietic pig cells was carried out according to the routine assay for human hematopoietic progenitor cells (SUTHERLAND et al, 1991) on methylcellulose medium MethoCult GF H4434. The effect of BS RNase on the growth of erythrocyte 
colonies (CFU-E and BFU-E) and of granulocytes (CFU-GM) was estimated as follows: $0,1 \mathrm{ml}$ of bone marrow cells suspension $\left(4 \times 10^{6} / \mathrm{ml}\right)$ was preincubated for $1 \mathrm{~h}$ with two concentrations of BS RNase $(100$ and $20 \mu \mathrm{g} / \mathrm{ml})$. The control samples were preincubated with $0.1 \mathrm{mI}$ of PBS. The pretreated cells were diluted in cultivation medium, then mixed with the methylcellulose medium to the final concentration $10 \mathrm{x}$ $10^{3}$ cells $/ \mathrm{ml}$ and cultivated in Petri dishes (Falcon $\varphi 35 \mathrm{~mm}$ ) for 14 days at $37^{\circ} \mathrm{C}$ under a humidified atmosphere containing $5 \% \mathrm{CO}_{2}$. The development of erythrocyte colonies (BFU-E) and granulocyte colonies (CFU-GM) were counted over the whole dish at $60 \mathrm{x}$ magnification in a binocular microscope.

\section{Indirect immunofluorescence}

Rabbit IgG was isolated from the serum of two rabbits immunized by three series of injections (one set 4 injections of $10 \mathrm{mg}$ of BS-RNase during 4 weeks) and used as an antibody to BS-RNase. Pig bone marrow cells were suspended in PBS, $\mathrm{pH} 7.2$ at the concentration $10 \times 10^{6} / \mathrm{ml}$. The cell suspension was incubated with $100 \mu \mathrm{g} / \mathrm{ml}$ BSRNase solution $1: 1$ at $37^{\circ} \mathrm{C}$ for $60 \mathrm{~min}$. After incubation and three washing with PBS, the cell suspension was spread on the slides, fixed with methanol, washed three times with PBS and rabbit IgG carrying anti-BS-RNase antibodies was added. Rabbit IgG bound to cell surface-associated BS-RNase was then detected by fluoresceinconjugated swine anti-rabbit globulin (Institute of Sera and Vaccines, Prague). The control cells were incubated with normal serum IgG instead of BS RNase one.

\section{Survival of pig bone marrow cells in BS-RNase suspension}

$1 \times 10^{8}$ pig bone marrow cells were suspended in $10 \mathrm{ml}$ MEM medium supplemented with $10 \%$ fetal calf serum and $5 \mathrm{mg}$ of BS-RNase. This suspension was kept in a refrigerator $\left(4^{\circ} \mathrm{C}\right)$ for 5 days and the viability of cells was estimated by trypan blue exclusion test (Sigma, St. Louis, USA) after 1, 24, 48, 72, 96 and $120 \mathrm{~h}$. The control samples contained $5 \mathrm{mg}$ of BSA instead of BS-RNase. Survival of bone marrow cells was estimated in 200 cells counted.

\section{Electron microscopy}

Bone marrow cells studied for survival experiments incubated $48 \mathrm{~h}$ with BS-RNase were centrifuged, fixed in $2.5 \%$ glutaraldehyde in $0.1 \mathrm{M}$ phosphate buffer for $60 \mathrm{~min}$., washed with $0.1 \mathrm{M}$ phosphate buffer and refixed in $1 \%$ osmium tetroxide in $0.1 \mathrm{M}$ phosphate buffer for an additional $60 \mathrm{~min}$. After washing with the buffer and dehydration in graded alcohol and acetone, the specimen was embedded in Durcupan ACM Fluka. Thin sections were cut on an LKB III ultramicrotome, stained with uranyl acetate and lead citrate, using a modification of the method (VENABLE and COGGESHALL, 1965) and examined in a JEM7A electron microscope at $80 \mathrm{kV}$.

\section{Antigenic characterization of donors and recipients}

The blood group and histocompatibility phenogroups were tested in all miniature pigs used as donors and recipients of bone marrow cells. Blood group antigens were serologically tested by 74 monospecific reagents by means of the direct agglutination test, antiglobullin (Coombs) test, dextran and haemolytic tests (JUNEJA and VÖGELI, 
1997; HOJNÝ and HRADECKÝ, 1971). The corresponding 73 phenogroups have been controlled from 16 locusses (JUNEJA and VÖGELI, 1997).

Histokompatibility antigens (in pigs SLA, SLB and SLC systems) belong to class I antigens (LUNNEY and BUTTER, 1997) and the corresponding SLA-A typing alloantisera have been developed mostly by repeated isoimmunization procedures in miniature pigs; the last international comparative test was reported by RENARD et al. (1988). The experimental pigs were tested by 6 standard antisera designated by W and 10 antisera specifically prepared by miniature pig immunization and designated the letter L (RENARD et al., 1988). SLB and SLC antigens are independent on SLA genes and there are genetically controlled in locusses designated B and C (HRUBAN et al., 1983,1988 ). These antigens are on pig leukocytes but not on erythrocytes. Seven SLB antigens are genetically controlled by 13 alleles (HRUBAN et aI., 1988) two SLC antigens are genetically determined by 2 alleles and this system is closed (HRUBAN et al., 1983). SLA, SLB and SLC antigens were determined at least by two different reagents.

\section{Irradiation procedure}

Nonanesthetized, fastened miniature pigs were irradiated using symmetric bilateral cobalt - 60 sources at the Medical Faculty, Hradec Králové. A single dose of 8 Grays total-body irradiation was given at $20 \mathrm{rads} / \mathrm{min}$ (SAKAMOTO et al., 1988). The bone marrow cells from a selected donor were infused into recipients $12-16 \mathrm{~h}$ after irradiation.

\section{Bone marrow transplantation}

The allogenic donor was anesthetized, exsanguinated and bone marrow harvested surgically from the humeruses, tibias and femures. Vertebral bodies and ribs were melted by a mincing mashine under aseptic conditions. Bone marrow cells were suspended in RPMI 1640 and incubated at room temperature. Suspensions were filtered through 100 mesh nylon gauze and centrifuged at $1200 \mathrm{rpm}$ for $15 \mathrm{~min}$. The cell pellet was 3 times washed and resuspended in RPMI 1640 medium supplemented with $5 \%$ normal pig serum, $100 \mathrm{U} / \mathrm{ml}$ penicilin, and $100 \mu \mathrm{g} / \mathrm{ml}$ of streptomycin. The bone marrow cell suspension was infused in a volume of 450 to $600 \mathrm{ml}$ into a recipient $\left(5 \times 10^{8}\right.$ cells $\left./ \mathrm{kg}\right)$ about $3 \mathrm{~h}$ after sampling. Seven irradiated recipients were infused with the suspension preincubated $2 \mathrm{~h}$ with BS-RNase $\left(10 \mathrm{mg} / 5 \times 10^{8}\right.$ cells $)$ while 8 control recipients received bone marrow preincubated with BSA (bovine serum albumin).

\section{Posttransplantation care}

Penicilin 400,000 I.U. and Streptomycin $400 \mathrm{mg}$ i.m. was injected daily starting on day 1. Biseptol $12 \mathrm{mg} /$ day into fodder, Supristol $120 \mathrm{mg}$ /day and $10 \%$ glukose were added into the drink from the first day after the transplantation and continued through day 16. Fresh whole blood from the donor $(200-300 \mathrm{ml})$ was given at day 7 as a source of platelets. Complete blood counts of recipients were examined daily and animals surviving more than 16 days were typed for blood group and histocompatible antigens. 


\section{Statistical analysis}

Results are presented as mean \pm standard error of mean (SEM). The data were analysed statistically using Fisher's t-test.

\section{Results}

\section{Effect of BS-RNase on colony-forming activity}

There were relatively large differences in the colony-forming activity of pig bone marrow cells between the single pigs. These individual differences were not influenced by the presence of BS-RNase in the cultivation medium. Both tested quantity of BSRNase in the medium (20 and $100 \mu \mathrm{g} / \mathrm{ml}$ ) did not change substantially the growth of granulocyte and erythrocyte colonies (Table 1).

Table 1

Effect of BS RNase on colony-forming activity of pig bone marrow cells

\begin{tabular}{cccccccc}
\hline & \multicolumn{2}{c}{ Controls } & \multicolumn{2}{c}{ BS RNase } & \multicolumn{2}{c}{ BS RNase $_{100}$} \\
Pig No. & CFU-GM & BFU-E & CFU-GM & BFU-E & CFU-GM & BFU-E \\
\hline 1 & 23 & 19 & 16 & 12 & 27 & 17 \\
2 & 13 & 5 & 7 & 10 & 7 & 7 \\
3 & 12 & 14.5 & 8.5 & 9 & 7.5 & 11 \\
4 & 24 & 9 & 25 & 11 & 25.5 & 9 \\
\hline mean \pm SEM & $18 \pm 10$ & $11.9 \pm 9$ & $14.1 \pm 14$ & $10.5 \pm 2$ & 16,8 & $11 \pm 6$ \\
\hline
\end{tabular}

Fach value in the table is a mean of a double assay. Indexes 20 and 100 of BS RNase represent the concentration of BS RNase ( $\mu \mathrm{g} / \mathrm{ml})$ in the cultivation medium.

\section{Binding of BS-RNase by pig bone marrow cells}

The binding of BS-RNase on the surface of bone marrow cells from 6 miniature pigs are shown in Figure 1 and Table 2. These cells were without any harmful effect (Fig. 2). Neither erythrocytes or unstimulated lymphocytes absorbed BS-RNase (data not shown).

Table 2

Immunofluorescence and survival of bone marrow cells of 5 pigs incubated with BS-RNase

\begin{tabular}{cccccccc}
\hline & & \multicolumn{5}{c}{ Per cent of dead cells incubated in hours } \\
\hline $\begin{array}{c}\text { Cells incubated } \\
\text { with MEM medium } \\
\text { and }\end{array}$ & $\begin{array}{l}\text { Immunofluorescence } \\
\text { after } 60 \mathrm{~min} \\
\text { incubation in } \%\end{array}$ & 1 & 24 & 48 & 72 & 96 & 120 \\
$5 \mathrm{mg} / \mathrm{ml}$ of BS-RNase & $71 \pm 13$ & $3 \pm 3$ & $10 \pm 7$ & $17 \pm 8$ & $23 \pm 12$ & $31 \pm 13$ & $42 \pm 17$ \\
$5 \mathrm{mg} / \mathrm{ml}$ of BSA & 0 & $2 \pm 3$ & $12 \pm 8$ & $23 \pm 7$ & $39 \pm 18^{\mathrm{x}}$ & $91 \pm 8^{\mathrm{xx}}$ & $94 \pm 11^{\mathrm{xx}}$ \\
\hline $\mathrm{x}=\mathrm{P}-0,02-0,01 ; \quad \mathrm{xx}=\mathrm{P}<0,01$ & & & & & & &
\end{tabular}

\section{Influence of BS-RNase on the survival of bone marrow cells}

Bone marrow cells $\left(1 \times 10^{8}\right)$ from 5 donors suspended in $10 \mathrm{ml}$ of MEM medium with $5 \mathrm{mg}$ of BS-RNase and kept at $4^{\circ} \mathrm{C}$ survived better in comparison to cells treated with $5 \mathrm{mg}$ of BSA, (Table 2). After $96 \mathrm{~h}$ storing 31 per cent of dead cells in the MEM medium with BS-RNase and 91 per cent in the medium with BSA were determined and after $120 \mathrm{~h}$ the values of dead cells were 42 and 94 per cent. 

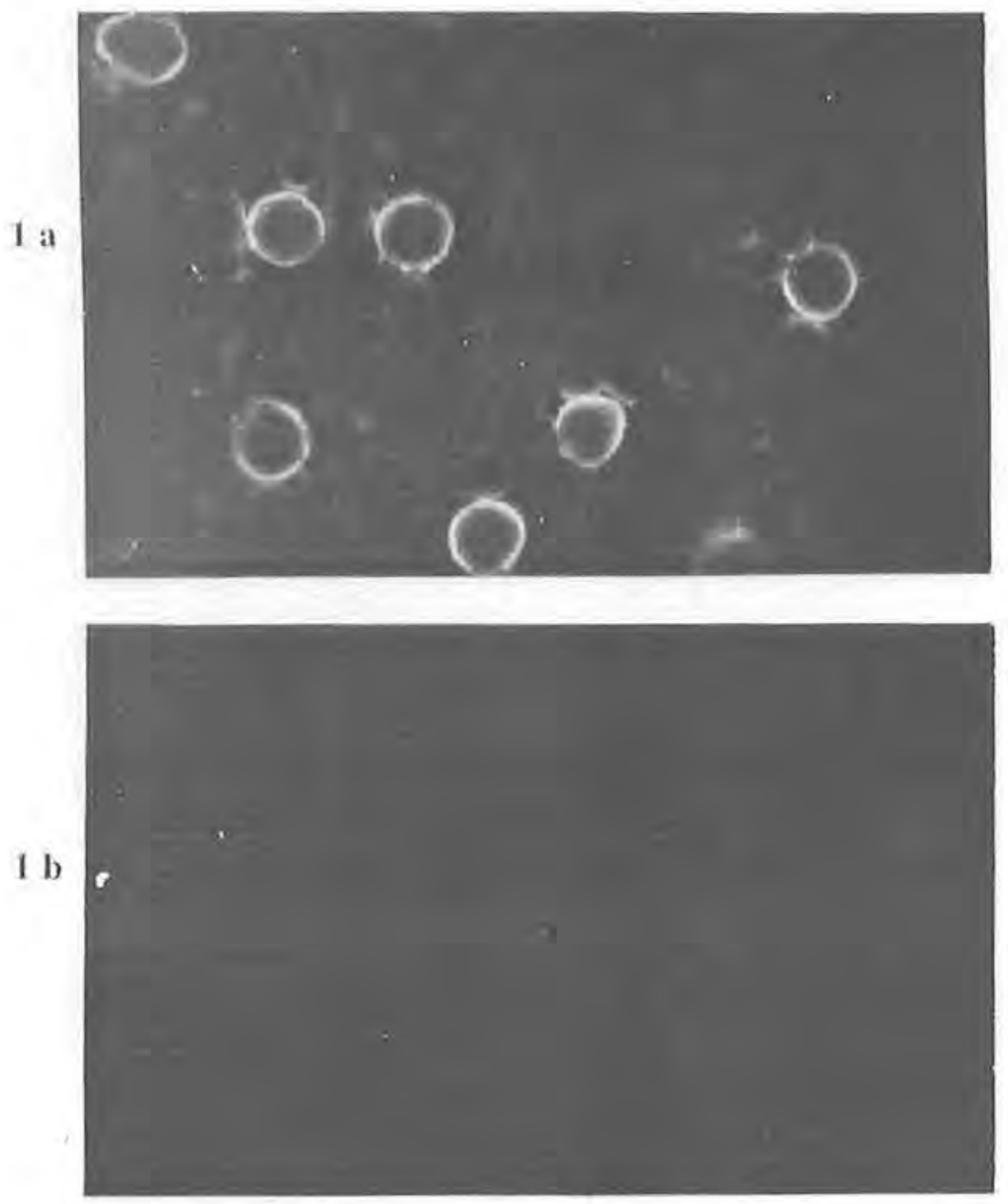

Fig. 1: Indirect immunofluorescence of bone marrow cells of miniature pig after $1 \mathrm{~h}$ incubation of cells with BSRNase at $24^{\circ} \mathrm{C}$

a) Strong membrane fluorescence was seen when rabbit IgG against BS-RNase was used. 1100x

b) Control - normal rabbit IgG instead of rabbit IgG against BS-RNase was used. 1100x

\section{Antigenic differences between recipients and donors}

Fifteen recipients were transplanted by the bone marrow cells of the 5 donors selected mostly from the same litter and the same sexes (Table 3 ). Only three recipients were transplanted by the bone marrow cells identical in SLA, SLB and SLC haplotypes with a donor, the other recipients obtained bone marrow cells that differed in histocompatibility haplotypes (Table 3 ). 


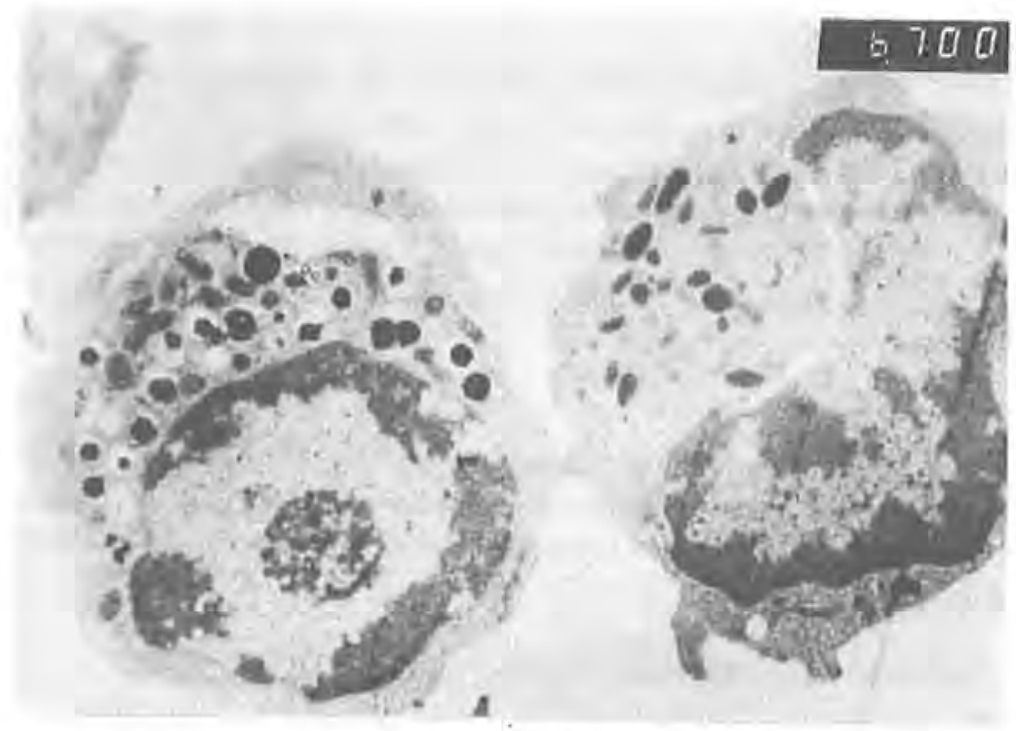

Fig. 2: Two bone marrow cells from a cell mixture incubated in MEM medium supplemented with 10\% fetal calf serum with $500 \mu \mathrm{g} / \mathrm{ml}$ of BS-RNase for $48 \mathrm{~h}$. Both plasmatic and nuclear membranes are without any damage. Cytoplasmic and nuclear components are also discernible and normal. $6200 \mathrm{x}$

Table 3

Histocompatibility antigens in donors and recipients and their relationships

\begin{tabular}{|c|c|c|c|c|c|}
\hline $\begin{array}{l}\text { No of donors/D/ } \\
\text { and recipients/R/ }\end{array}$ & $\begin{array}{l}\text { Relationship of } \\
\text { donors to } \\
\text { recipients }\end{array}$ & Genotypes of & antigens in & systems & $\begin{array}{c}\text { Antigenic } \\
\text { difference } \\
\text { between donors } \\
\text { and recipients }\end{array}$ \\
\hline $2 \mathrm{Df}^{1}$ & & L $2.8 / \mathrm{L} 2.8$ & $4 / 4$ & $1 / 2$ & \\
\hline $1 \mathrm{Rf}$ & sister & L $2.8 / \mathrm{L} 2.8$ & $4 / 4$ & $1 / 2$ & 0 \\
\hline $3 \mathrm{Rf}$ & sister & L $2.8 / \mathrm{L} 2.8$ & $4 / 4$ & $1 / 2$ & 0 \\
\hline $4 \mathrm{R} \mathrm{f}$ & sister & L $9.10 /$ L 9.10 & $4 / 4$ & $1 / 2$ & L 2.8 \\
\hline $41 \mathrm{D} \mathrm{m}^{2}$ & & L $1.4 / \mathrm{L} 9.10$ & $4 / 4$ & $2 / 2$ & \\
\hline $38 \mathrm{R} \mathrm{m}$ & brother & L 9.10/L 9.10 & $3.4 / 4$ & $1 / 1$ & L $1.4,2$ \\
\hline $39 \mathrm{R} \mathrm{m}$ & brother & L $1.4 / \mathrm{L} 9.10$ & $3.4 / 4$ & $1 / 2$ & 0 \\
\hline $60 \mathrm{Dm}$ & & L $9.10 / \mathrm{L} 2.7$ & $3.4 / 7$ & $2 / 2$ & \\
\hline $44 \mathrm{R} \mathrm{m}$ & half sib & L $9.10 / L 9.10$ & $3.4 / 7$ & $2 / 2$ & L 2.7 \\
\hline $57 \mathrm{R} \mathrm{m}$ & brother & L $9.10 / L 9.10$ & $4 / 7$ & $1 / 1$ & L $2.7,3.4,2$ \\
\hline $58 \mathrm{R} \mathrm{m}$ & brother & L $1.4 / \mathrm{L} 2.7$ & $1.5 / 3.4$ & $2 / 2$ & L $9.10,7$ \\
\hline $42 \mathrm{R} \mathrm{m}$ & brother & L $1.4 / \mathrm{L} 9.10$ & $3.4 / 4$ & $2 / 2$ & L $2.7,7$ \\
\hline $63 \mathrm{D} \mathrm{m}$ & & L $2.7 / \mathrm{L} 9.10$ & $4 / 7$ & $1 / 2$ & \\
\hline $59 \mathrm{R} \mathrm{m}$ & brother & L $1.10 / \mathrm{L} 9.10$ & $4 / 7$ & $2 / 2$ & L 2.7 \\
\hline $81 \mathrm{R} \mathrm{m}$ & half sib & L $9.10 / L 9.10$ & $4 / 4$ & $1 / 2$ & L $2.7,7$ \\
\hline $90 \mathrm{Rf}$ & half sib & L $9.10 / L 9.10$ & $3.4 / 4$ & $2 / 2$ & L 2.7. 7,1 \\
\hline $489 \mathrm{D} \mathrm{m}$ & & L $11 / \mathrm{L} 9.10$ & $2 / 3.4$ & $1 / 2$ & \\
\hline $42 \mathrm{R} \mathrm{m}$ & non-related & L $1.4 / \mathrm{L} 9.10$ & $3.4 / 4$ & $2 / 2$ & L $11,2,1$ \\
\hline $48 \mathrm{R} \mathrm{m}$ & non-related & L $9.10 / L 9.10$ & $1.5 / 3.4$ & $1 / 2$ & L 11,2 \\
\hline $49 \mathrm{R} \mathrm{m}$ & non-related & L $9.10 / \mathrm{L} 9.10$ & $3.4 / 3.4$ & $2 / 2$ & 2,1 \\
\hline
\end{tabular}




\section{Haematological changes}

The irradiation exerted a profound leucopoenia in all animals, After a rapid fall after the irradiation the decrease in leucocyte counts continued up to 10-14 days. Number of leucocytes $12 \times 10^{3} / \mathrm{mm}^{3}$ before irradiation decreased to $7 \times 10^{2} / \mathrm{mm}^{3}$ in two weeks after the transplantation. The number of erythrocytes did not change so much as that of leucocytes $\left(6 \times 10^{6}\right.$ to $\left.3-5 \times 10^{6}\right)$ after the transplantation. In the pig no 4 that survived more than 2 years the number of lymphocytes normalized after 50-60 and erythrocytes after 30 to 40 days.

\section{Disease and mortality}

Recipients after irradiation and transplantation suffered from haemorrhage, crusting pneumonia and severe infections. Some animals were killed in a state of sever cachexia. Occasional hyperthermic periods, diarhea and bleeding were also observed in spite of antibiotic therapy.

\section{Anti-SLA, SLB and SLC antibody production in transplanted pigs}

The appearance of leucocytotoxic antibodies was looked for almost in all of the serum samples drawn during the experimental period. Specificity studies on a panel of cells have shown that cytotoxic activity is directed against leucocyte antigens. The titres of antibodies declined from 0 to $1: 4$ both in recipients transplanted with cells incubated with BS-RNase or without this enzyme.

\section{Transplantation results}

Three recipients (no 1, 3, 39) that received compatible bone marrow cells in SLA, SLB and SLC antigens from their sister and brother (Table 3) died 12, 15 and 17 days after transplantation. The donor's cells for the recipient 39 were preincubated with BSRNase, and the recipients no 1 and 3 by BSA. The crusting in skin, lung, intestines and liver was observed after the death during autopsy as nose bleeding in last three days of life in recipients 1 and 3 . The animal 39 died of systemic infection without any crusting in the skin and body organs, but with the decreased number of leucocytes $850 / \mathrm{mm}^{3}$ and erythrocytes $3 \times 10^{6} / \mathrm{mm}^{3}$.

The next recipients $4,38,44,57,81$ and 48 received bone marrow cells from SLA semi-incompatible genotyped donors (Table 3 ) treated for $2 \mathrm{~h}$ with BS-RNase. The pigs 4 and 57 that differed from the donors of the same litter in L2.8 and L2.7,3.4,2 antigens accepted the donor bone marrow cells. These animals remained alive up to 26 months when the recipient 4 was killed and up to 33 days when the recipient 57 died. The number of leucocytes in the recipient 4 decreased from 4.400 before transplantation up to 600 on the 7 day after the transplantation. The erythrocytes decreased from $7,2 \times 10^{6}$ up to $3,2 \times 10^{6}$. The number of the blood cells decreased in the recipient 57 from 5.100 up to 920 of leucocytes and from $6,6 \times 10^{6}$ up to $5,9 \times 10^{6}$ of erythrocytes per $1 \mathrm{~mm}^{3}$ of blood. During the next 15 days (22 days after transplantation) the number of blood cells increased potently in the pig 4 to 6.800 of (leucocytes) and 3,930.000 of (erythrocytes) and in the pig no 57 to 4.010 leucocytes. The erythrocytes of this pig decreased into $5,3 \times 10^{6} / \mathrm{mm}^{3}$. In this time all supported medicaments were removed, and these two recipients transported into the common 
stable with other pigs. By means of analysis of histocompatibility and blood group antigens of these two recipients was found that they obtained 50-90 per cent of erythrocytes and 100 and 80 per cent of leucocytes from their donors. The following 7 and 2 (in the pig 57) screenings of antigens in the recipients confirmed again the presence of donor antigens in their blood.

The next recipients no $38,44,81$ and 48 that were transplanted by donor's semi-in compatible bone marrow cells incubated with BS-RNase died between 9-16 days after the transplantation. Haemorrhage in skin, intestines, lung, stomach and haemoglobin in the urine were diagnosed in them.

The recipients transplanted by donor's semi-incompatible bone marrow cells incubated instead of BS-RNase by BSA (no 58, 59, 92, 42, 48 and 49) died between 8 and 14 days. The number of leucocytes decreased 7 days after the transplantation in the recipient no 42 up to 400 and number of erythrocytes up to $1,010.000$ in $1 \mathrm{~mm}^{3}$ of blood. In the other recipients transplanted by donor's cells incubated with BSA the number of blood cells moved similarly as in pigs transplanted by bone marrow cells incubated with BS-RNase. All recipients of this group suffered by haemorrhage on skin, intestines, some of them on liver and stomach, haemoglobin in urine and bleeding from noses.

\section{Discussion}

Experiments with miniature pigs were performed to establish the effect of the bovine seminal ribonuclease (BS-RNase) on bone marrow cells in vitro and in vivo. Previously the immunosuppressive effect of this enzyme on $T$ and B blastic transformation lymphocytes in bovine, pig and human (STANĚK et al., 1978, 1982; SOUĆEK et al., 1981, 1986, 1996) without any harmful effect on NK cells was reported. Our former experiments showed that BS RNase inhibited regional GVH reaction, caused significant prolongation of a skin graft survival and enhanced formation of GM-CFC colonies in mice and man (SOUČEK et al., 1983, 1986).

As new experiments, the binding of BS-RNase to normal bone marrow cells of pigs and the effect of this enzyme on the survival of pig's bone marrow cells incubated 5 days in a refrigerator were investigated. Both experiments proved the ability of pig bone marrow cells to absorbed this enzyme and the positive effect of BS-RNase on the viability of these cells during 5 days storage in $4^{\circ} \mathrm{C}$. In contrast to previous experiments in human (SOUČEK et al., 1986, 1996) and mice (SOUČEK et al., 1983), the colony-forming activity in pig bone marrow cell culture was not enhanced in the presence of BS RNase.

Our irradiation and transplantation protocols used were inspired by the work of VAIMAN et al. (1981) studying skin and kidney grafts after partial lateral and conventional total lymphoid irradiation and bone marrow cell grafting. Our results although obtained with a limited number of bone marrow transplanted animals indicated a certain favourable effect of BS-RNase on the acceptance of donor bone marrow cells. Two recipients from 7 ones accepted donor cells while no animal from 8 recipients received donor's bone marrow cells pre-treated with BSA instead of BSRNase. In above mentioned successful recipients the detectable chimerism in 
leucocyte and blood group antigens was obtained and the pig 4 survived more than two years.

The surviving of recipients was probably also dependent on the lymphocyte and platelet levels after the irradiation and transplantation. The lowest number of lymphocytes and erythrocytes was observed from the forth day after the irradiation. Anaemia (mainly leukopenia) and probably trombocytopenia continued on individual dependence up to the death or up to the 17 days in the recipient no 4 transplanted by the donor's cells incubated by BS-RNase. The similar restoration of lymphocytes in partial lateral irradiation of pigs was published (VAIMAN et al., 1981; SAKAMOTO et al., 1988).

Experiments with SLA, SLB and SLC compatible donor - recipient pairs were performed only on three recipients. However, in all these three cases the animals died between 12 and 17 days after the transplantation. Probably there was a difference in histocompatibility antigens which were not tested by our antisera because in the animal no 3 the GVH-like reaction was possible to recognise from the skin and organ rashes. Of course, the other transplantation antigens could play a role in this unexpected phenomenon.

\section{Acknowledgements}

We thank Mrs. Miluše Hokešová for excellent technical assistance. This work was supported by grants from the Grant Agency of the Czech Republic (no 523/01/0114) and European Union (INCOCopernicus, contract no. ICISCT 960903).

\section{References}

D ALESSIO, G.A.; DIDONATO, A.; PARENTE, A.; PICCOLI; R.: Seminal RNase: A singular member of the ribonuclease super family. Trends Biochem. Sci. 16 (1991), 104-106

DE NIGRIS, M.; ROSSO, N.; PICCOLI, R.; D'ALESSIO, G.; DIDONATO, A.: Expression of bovine seminal ribonuclease in Escherichia coli.. Biochem. Biophys. Res. Commun. 193 (1993), 155-160

DOSTÁL, J, MATOUSEK, J.:

Isolation and some chemical properties of aspermatogenic substance from bull seminal vesicle fluid. J. Reprod. Fert. 33 (1973), 263-274

HONNÝ, J.; HRADECKÝ, J.: The time and appearance of blood group antigens in miniature pigs. Anim. Blood Grps. Biochem. Genet. 2 (1971), 105-112

HRUBAN, V; HRADECKÝ, J:; DVORAK, P: Polymorphism of the SLB serologically defined (non-MHC) alloantigenic system in pigs. Anim. Genet. 19 (1988), 285-290

HRUBAN, V.; DVOR̈AK, P.; HRADECKÝ, J.; PAZDERA, J,; MULLER, J.:

Non-MHC alloantigenic system in pigs (SLC) detected by leucoagglutination. Anim. Blood Grps. Biochem. Genet. 14 (1983), 299-304

JUNEJA, R.K.; VÖGLLI, P.: Biochemical Genetics. In Genetics of Pigs (Eds. ROTHSCHILD, M. F, and A. RUVINSKY) p. $105-$ 134, CAB International, New York. 1997

KIM, J.S.; RAINES, R.T: Bovine seminal ribonuclease produced from a synthetic gene. J. Biol. Chem. 268 (1993), 17392-17396

KIM, J.S.; SOUČEK, J.; MATOUŠEK, J.; RAINES, R.T.: Structural basis for the biological activities of bovine seminal ribonuclease. J. Biol. Chem. 270 (1995), $10525-10530$

LUNNEY, J.K,; BUTTER, J.E.: Immunogenetics. In Genetics of Pigs. (Eds. ROTHSCHILD, M.F.. and A. RUVINSKY) p. 163-197, CAB International, New York. 1997 


\section{MATOUŠEK, J.:}

Biological and immunological roles of proteins in the sperm of domestic animals (review). Anim Reprod. Sci. 8 (1985), 1-40

MATOUSEK, J.; KLAUDY, J.:

Qualitative and quantitative analysis of seminal ribonuclease in reproductive tract fluids of bulls. Anim Reprod. Sci. 51 (1998), 111-118

RENARD, C.; KRISTENSEN, B; GAUTSCHI, C.; HRUBAN, V.; FREDHOLM, T; VAIMAN, M.: Joint report of the First International Comparison Test on Swine Alloantigens (SLA). Anim. Genet. 19 (1988), 63-72

SAKAMOTO, K.; SACHS, D.H.; SHIMIDA, S.; POPITZ-BERGEZ, F.A.; PENNINGTON, L.R.; PESCOVITZ, M.D.; MCDONOUGH, M.A.; MACVITTIE, T.J.; KATZ, S.I.; GRESS, R.E.:

Bone marrow transplantation in miniature swine. III. Graft. Versus - host disease and the effect of T cell depletion of martow. Transplantation 45 (1988), 869-875

SHIVAJ, S; SCHEIT, K.H.; BHARGAVA, P.M.: Proteins of Seminal Plasma, Wiley, New York. 1990

SOUČEK,J.; CHUDOMEL, V.; POTMĚ́̇LLVÁ, I.; NOVẢK, J.T.;

Effect of ribonucleases on cell mediated lympholysis reaction and on GM-CFC colonies in bone marrow culture. Nal. Immun. Cell Growth Regul. 5 (1986), 250-258

SOUČEK, 1, HRUBA, A.; PALUSKA, E.; CHUDOMEL, V.; DOSTAL, J.; MATOUŠEK, J.:

Immunosuppressive effects of bovine seminal fluid fractions with ribonuclease activity. Folia Biol (Prague) 29 (1983), 250-261

SOUČEK, J.; MARINOV, I.; BENEŠ, J.; HLGERT, I.; MATOUŠEK, J.; RAINES, R.T.

Immunosuppressive activity of bovine seminal ribonuclease and its mode of action. Immunobiol. 195 (1996), 271-285

SOUČEK, J.; MATOUß̌EK, J.; CHUDOMEL, V.; LINDNEROVÅ, G.:

Inhibitory effect of bovine seminal ribonuclease on activated lymphocytes lymphoblastoid cell lines in vitro. Folia Biol. (Prague) 27 (1981), 334-345

STANÉK, R. ĊECHOVÄ, D.; VESELSKÝ, L.:

Activity of bull seminal plasma components on DNA synthesis of homologous lymphocytes. Proc. XI Anim. Genet. Days, Hradec Kralové, 220, 1982

STANĚ̃K, R.; ČINẢTL, J.; MATOUŠEK, $J$ :

The effect of boyine pancreatic (A RNase) and bull seminal ribonuclease (AS RNase) on human lymphocytes undergoing blastic transformation. Folia Biol. 24 (1978), 111-117

SUTHERLAND, H.J.; EAVES, C.J.; EAVES, A.C.: Quantitative assays for human hemopoetic progenitor cells. In Bone Marrow Processing and Purging: A Practical Guide (Ed. GEE, A.P.) p. 155-171, CRC Press Inc. 1991

TAMBURINI, M.; SCALA, G.; VERDE, C.; RUOCCO, M.R.; PARENTE, A.; VENUTA, S.; D ALESSIO, G.: Immunosuppressive activity of bovine seminal RNase on T - cell proliferation. Eur. J. Biochem. 190 (1990), 145-148

VAIMAN, M; DABUSON, F; REMY, J.; VILLIERS, P.A.; DE RIBEROLLES, C $;$; LECOMTE, Y; MAHOUY, G.; FRADELIZI, D.:

Allograft tolerance in pigs after fractionated lymphoid irradiation. I. Skin grafts after partical lateral irradiation and bone marrow cell grafting. Transplantation 31 (1981), 358-364

VENABLE, J.H.; COGGESHALL, R.;

A simplified lead citrate stain for use in electron microscopy, J. Cell Biol. 25 (1965), 407-4I3

Received: 1999-03-01

Accepted: 2000-05-17

Author's addresses

Dr. JOSEF MATOUŠEK, Dr. JAN HRADEKCÝ

Institute of Animal Physiology and Genetics

Academy of Sciences of the Czech Republic

27721 Liběchoy, Czech Republic

Dr. JOSEF SOUČEK,

Dr. ALENA HRUBA

Institute of Haematology and

Blood Transfusion

Prof. Dr. VOJTECH HRUBAN

12820 Prague 2, Czech Republic

Department of Animal Science

University of Agriculture

16000 Prague- Suchdol, Czech Republic 
Arch. Tierz., Dummerstorf 44 (2001) 1, 64

\section{Buchbesprechung}

\section{Forschung ohne Tierversuche 2000}

\section{H. SCHÖFFL, H. SPIELMANN, F.P. GRUBER, H. APPL, F. HARRER, W. PFALLER, H.A. TRITTHART}

471 Seiten, 119 Abbildungen, Tabellen, Springer Verlag, Wien - New York, 2000, ISBN 3-211-83046-4, DM 140,$00 ; 8 \mathrm{~S} 980,00$; sFr 127,50

Im Rahmen der Buchreihe „Ersatz- und Ergănzungsmethoden zu Tierversuchen", die von SCHÖFFL, SPIELMANN und TRITTHART herausgegeben wird, liegt inzwischen der 6. Band vor. Er enthălt die Vorträge und Poster der 6, 7, und 8, internationalen Kongresse uber Ersatz- und Ergänzungsmethoden zu Tierversuchen (TV), die innerhalb eines Jahres in Linz/Österreich stattfanden.

Tierschutz (TS) ist gezielte Hilfe fur das Tier und TS-Gesetze dienen dieser Hilfe, indem sie das Leben und das Wohlbefinden der Tiere schlitzen. Es ist ein erklärtes Ziel Tierversuche einzuschrănken. Sie sind trotz erforderlicher Genehmigungsverfahren umstritten, zumal bei der Interpretation dessen, was als ethisch vertretbar angesehen wird, sich ein weites Feld unterschiedlicher Betrachtungsmöglichkeiten bietet. Im Gegensatz zu Vertretern, die eine generelle Abschaffung von Tierversuchen fordern, ist die erfolgreiche Suche nach Ersatz- und Ergănzungsmethoden für Tierversuche das verdienstvolle Anliegen dieses und der bereits vorliegenden Tagungsberichte. Ermøglicht er es doch dem Leser sich umfassend uber diesbezügliche internationale Aktivităten und wissenschaftliche Fortschritte im sensiblen Bereich der Entwicklung solcher Methoden zu informieren. Er trägt aber auch wesentlich zum objektiven Verstandnis dieser häufig emotional diskutierten Thematik bei. Dieses Buch macht aber auch deutlich, dass bei uberaus wonschenswerter Einschrankung bzw. bei Ersatz- und Ergänzungsmethoden in den verschiedenen Anwendungsbereichen, vor allem bei der biomedizinischen Forschung, die Ersetzbarkeit oder Kombination mit anderen Methoden möglich ist, immer aber mit zumindest gleichwertigen bzw. besseren Ergebnissen verbunden sein muss. Thematische Vielfalt kennzeichnet den vorliegenden 6, Band dieser Reihe. Das Spektrum reicht von Beitragen zur Standardisierung von Zellkulturen bis hin zu Einsatzmöglichkeiten von Alternativen zu Tierversuchen in der universitaren und chirurgischen Ausbildung. Nach zwei einleitenden Gastbeiträgen folgen 52 Einzelvorträge in 16 Themenkomplexen folgenden Inhalts:

- EU-Target 2000 - können die Tierversuchszahlen des Jahres 1992 bis zum Jahr 2000 halbiert werden

- Standardisierung von Zellkulturen und neue Entwicklungen

- Rechtliche und asthetische Fragen

- TS-relevante Forderung in Europa

- Abschaffung von Tierversuchen fur Kosmetika

- Das Prinzip der quantitativen Struktur-Wirkungsbeziehungen in der 3R-Forschung

- Pyrogentestung im menschlichen Vollblut

- Ergebnisse von Validierungsstudien

- Ersatz- und Ergänzungsmethoden in der onkologischen Forschung

- 3R-Relevanz transgener Tiere

- Ökotoxikologie

- Tierversuche in der universităren Ausbildung

- Aviăre Antikörper

- Standardisierung von Zellkulturen

- Behordliche Akzeptanz von in vitro Tests zur Prufung von Ätzwirkung an der Haut

- Ersatz- und Erganzungsmethoden in der chirurgischen Ausbildung

- Normotherm hamoperfundierte Schlachthoforgane des Schweines, als Ersatz- und Ergänzungsmethode zu TV

- Refinement und TS

- Ersatz- und Ergänzungsmethoden in der chirurgischen Forschung.

Den Abschluss des Buches bildet die Vorstellung von 61 Posterbeiträgen zu diesen Themenkomplexen. Wie kein anderes Buch, ermoglicht auch dieser 6. Band sich aktuell und komplex lber Aktivitäten und Möglichkeiten auf diesem Gebiet zu informieren. Hilfreich fur die Kommunikation ist auch das Anschriftenverzeichnis der Autoren und Posterautoren. Das Buch richtet sich in erster Linie an auf diesem Gebiet Tatige in Lehre, Forschung und Indostrie. Es kann aber auch fur einen weit größeren Leserkreis, einer an Objektivitalt interessierten Öffentlichkeit, das ernsthafte Bemuhen der Wissenschaft um den Ersatz von Tierversuchen demonstrieren. 